\title{
POTENTIAL AMELIORATIVE ROLE OF SILYMARIN AGAINST METHYL PARATHION-INDUCED OXIDATIVE STRESS AND HEPATO-RENAL TOXICITY IN ALBINO RATS
}

\author{
$B \mathcal{Y}$ \\ Mohammed F. Khodeary, Abeer A. I. Sharaf El-Din, Shereen M. S. El Kholy, \\ Atef A. Fouda and Essam M. Mehlab* \\ Departments of Forensic Medicine and Clinical Toxicology and Anatomy* \\ Faculty of Medicine, Benha University
}

\begin{abstract}
Methyl parathion (MP) (C8H10NO5PS) is an organophosphate insecticide that has been used in agriculture for several years. The people who are at the greatest risk of being exposed to MP are farm workers, chemical sprayers, and people who work in factories handling MP. The main route of human exposure is inhalation, but dermal contact and inadvertent ingestion can also be substantial. The present work was planned to study the toxic effects of MP on some antioxidative markers as well as the liver and kidney. The influence of silymarin (Sily) on MP induced toxicity has not been studied, So, the possible protective effect of (Sily) had been also evaluated. The study was conducted on one hundred male albino rats divided into five main equal groups and each of them were subdivided equally into two subgroups. Group-I (A\&B), control group: received no treatment, group-II (A\&B): vehicle group (1 ml/kg/day of corn oil, P.O.), group-III (A\&B): Sily group (100 mg/kg/day, P.O.), group-IV (A\&B): MP group (0.28 $m g / k g / d a y, P . O)$, group $-V(A \& B):$ Sily $+M P$. At the end of $4^{\text {th }}$ and $8^{\text {th }}$ weeks, blood samples, renal and hepatic tissues were collected for biochemical and histological examinations. Biomarkers selected for oxidative stress were antioxidant defense system superoxide dismutase (SOD) and reduced glutathione $(G S H)$ as well as malondialdehyde (MDA). In addition, liver profile (AST, ALT, and ALP) and kidney profile (Blood urea and creatinine) were assessed. Also, histological examination of liver and kidney was done. The results showed that administration of MP resulted in oxidative stress as evidenced by significant decrease in SOD activity and GSH levels accompanied with significant increase in MDA levels. At the same time, there was hepato-nephrotoxicity as manifested by significant increase in liver and kidney function tests when compared with control rats. Comparing with MP-treated rats, Sily supplementation to the rats, 30 minutes before MP administration, resulted in a significant increase in SOD activity and GSH levels. However, MDA levels, liver and kidney enzymes showed significant decrease. The histopathological results confirmed the biochemical results. In conclusion, the obtained biochemical and histological results of this study revealed hepatic and renal toxic effects induced by MP in a time-dependent manner. Sily supplementation resulted in a remarkable protective effect against MP-induced oxidative stress and hepato-renal toxicity.
\end{abstract}




\section{INTRODUCTION}

Organophosphorous (OP) compounds have been used worldwide for pest control for over 100 years. They are the insecticide of choice in the agricultural world and are the most common cause of poisoning among the organic insecticides as a result of their readily availability and easy accessibility (Eddleston, 2000). The common use of insecticides in public health and agricultural schedules has caused severe environmental pollution and potential health hazards including severe acute and chronic cases of human and animal poisonings (Abdollahi et al., 2004).

OP compounds are known to cause inhibition of acetylcholinesterase and pseudocholinesterase activity (Yavuz et al., 2005). Other systems that could be affected by OP compounds are urinary system (Rod-rigo et al., 2001) and liver (Kalender et al., 2005).

Methyl parathion (MP; O, O-dimethyl O-P-nitro-phenyl phosphorothioate), popularly known as "cotton poison", is an organophosphate insecticide licensed only for agricultural use in many countries, although there are instances of its misuse as a domestic spray (Rubin et al., 2002).

People may be exposed to MP via a number of several ways. Applicators and manufacturers of this product may be exposed occupationally, although, there are some individuals who are exposed via food and water. Illegal application of MP increases the risk of exposure to the chemical for those who do not have occupations that involve MP handling. Individuals residing near hazardous waste disposal sites may be subject to higher levels of MP exposure (ATSDR, 2001).

MP insecticidal properties reside in its ability to inhibit acetylcholinesterase activity, thus enhancing endogenous acetylcholine accumulation (Comoglio et al., 2005).

Besides their inhibitory effects on ace-tylcholinesterase enzymes, OP compounds may induce oxidative stress leading to generation of free radicals and alterations in antioxidants status or reactive oxygen species (ROS) scavenging enzymes (Gultekin et al., 2000).

The lipophilic nature of OP facilitates their interaction with the cell membrane and leads to perturbation of the phospholipids bilayer structure (Videira et al., 2001). Therefore, they may enhance lipidperoxidation (LPO) by directly interacting with the cellular membrane and generated ROS (Aslan et al., 1997). LPO may impair antioxidant defenses, leading to cellular oxidative damage by changing the balance between oxidants and antioxidants (Torres et al., 2004). Some studies showed that 
LPO has been suggested as one of the molecular mechanisms involved in OP compounds induced toxicity (Yamano and Morita, 1992). Hence, treatment with antioxidants and free radical scavengers can decrease the oxidative stress related to OP-induced toxicity(Yurumez et al., 2007).

Nutritional studies have also revealed the crucial role of some minerals in preventing oxidative stress. Nutritional and botanical supplementation was also suggested for chronic pesticide detoxification. A high quality multiple vitamin/ mineral supplements with extra magnesium, pyridoxine, selenium, antioxidants, and milk thistle is recommended (Walter and Crinnion, 2000). Moreover, silymarin/silybin and their preparations are advocated for the treatment of various diseases like cirrhosis, chronic hepatitis and diseases associated with alcohol consumption and environmental toxin exposure (Koen and Walterovab, 2005).

Silymarin (Sily) is a purified extract from the seeds of Silybum marinum L. (As-teraceae) which also called "milk thistle". It is shown that Sily consists of a large number of flavolignans, including silybin (or silybinin), which is the most active component, isosilybin, silydianin and silychristin (Khan et al., 2006).

Sily acts as a powerful antioxidant that can capture and neutralize the harmful free radical species. This action as well as many other beneficial intracellular reactions have adverted it as promising agent for protection and treatment of the damaging actions of many toxic compounds (Dalmi and Sari, 1992).

The goal of the current study was to investigate the toxic effects of MP on some serum antioxidative markers as well as the liver and kidney of male adult albino rats and also to evaluate the possible protective role of Sily in modulating these toxic effects.

\section{MATERIAL AND METHODS}

\section{Animals:}

The study was conducted on 100 adult male albino rats with initial body weight ranging between 180-200 grams. All animals were housed under suitable environmental conditions with free access to food and water. In order to exclude fallacies induced by environmental factors, the rats received standard laboratory environmental conditions according to Cuschieri and Backer (1977). The rats had been familiarized with the environment for one week before the study to allow acclimatization.

\section{Drug and Chemical :}

Methyl parathion (MP) was obtained from Sigma Agency for Chemicals and Pharmaceuticals, Cairo, Egypt. It was 
available in a white crystalline powder form, which was dissolved in corn oil.

Silymarin was obtained from commercially marketed packets containing 140 mg of silymarin powder/packet (Sedico Pharmaceuticals Co. Cairo). The powder was dissolved in distilled water.

\section{Experimental Groups:}

One hundred male rats were divided equally into 2 groups, $A$ and $B$, each compromised 50 rats. Groups A and B were further subdivided into 5 subgroups each consisted of 10 rats. Animals in groups A and $B$ received their corresponding substance for 4 and 8 weeks, respectively and distributed as follows:

Group-I $(A \mathcal{E} B)$ : Control group, the animals received no treatment, only they gavaged with $1 \mathrm{ml}$ of distilled water daily for 4 and 8 weeks and were used to determine the normal values of tested parameters.

Group-II $(A \mathcal{E} B)$ : Vehicle group, each animal gavaged with corn oil at a dose of $1 \mathrm{ml} / \mathrm{kg}$ body weight for 4 and 8 weeks.

\section{Group-III $(A \mathcal{E} B)$ : Silymarin-treated} group, each animal received silymarin orally in a dose of $100 \mathrm{mg} / \mathrm{kg}$ body weight for 4 and 8 weeks (Crocenzi et al., 2003).

Group-IV $(A \mathcal{E} B)$ : Methyl parathion treated group, each animal received MP orally in a dose of $0.28 \mathrm{mg} / \mathrm{kg}$ body weight (1/50 LD50 dose orally) for 4 and 8 weeks (Kalender et al., 2007).

Group-V $(\boldsymbol{A} \mathcal{E} B)$ : Methyl parathion + Silymarin-treated group, each animal received silymarin $(100 \mathrm{mg} / \mathrm{kg} /$ day, orally through gavage), 30 minutes before administration of MP $(0.28 \mathrm{mg} / \mathrm{kg} /$ day orally through gavage) in corn oil.

Animals were fasted for 4 hours before gavage and received their corresponding substance dosage once daily.

\section{Experimental Parameters :}

\section{Biochemical parameters}

No deaths were observed in any of the experimental groups during different periods.

Twenty four hours after the end of $4^{\text {th }}$ and $8^{\text {th }}$ weeks, the animals were anesthetized with sodium pentobarbital $(50 \mathrm{mg} /$ $\mathrm{kg}$ intraperitoneally) before sacrification. Following this laparotomy was conducted and the intra-abdominal organs were exposed and the blood was collected from the descending aorta. For each animal, a portion from collected blood was transferred into a heparinized centrifuge tube for spectrophotometric determination of plasma malondialdhyde (MDA) level (Yoshida et al., 1980), reduced glutathione (GSH) level (Hissin and Hilf, 1976), and the activity of superoxide dismutase (SOD) (Kakkar et al., 1984). 
The remainder of each sample was centrifuged and the serum was separated for spectrophotometric determination of aspartate transaminase (AST), and alanin transaminase (ALT) according to Frankel and Gradwohl, (1970) and alkaline phosphatase (ALP) (Donald and Ralph, 1993). Also, spectrophotometric determination of (BU) and creatinine levels according to Lawrence and Robert (1993).

\section{Histopathological Examination:}

After the animals were sacrificed, the liver and kidney were dissected out and fixed in $10 \%$ formol saline. Paraffin sections of 5-7 $\mu \mathrm{m}$ in thickness were prepared and subjected to Hematoxylin-Eosin (Hx \& E) according to Drury and Wallington (1980).

\section{Statistical Analysis:}

The experimental data are expressed as mean \pm S.D. The data were analyzed by the student t-test. The differences were considered to be statistically significant when $\mathrm{P}<0.05$.

\section{RESULTS}

\section{Biochemical Results}

\section{I.1 Oxidative stress biomarkers (Table 1) :}

\section{I.1.A. Control Vs vehicle-treated groups :}

At the end of $4^{\text {th }}$ and $8^{\text {th }}$ weeks, the results of the present study revealed non significant changes in SOD, GSH, and MDA values, when vehicle treated groups were compared with control groups.

\section{I.1.B. Control Vs Sily-treated groups :}

Sily induced significant increase in SOD and GSH values accompanied with significant decrease in MDA levels at the end of 4th and 8th weeks. These effects were more pronounced after $8^{\text {th }}$ than $4^{\text {th }}$ weeks of Sily administration to rats.

\section{I.1.C. Control Vs MP-treated groups :}

In MP treated groups, SOD and GSH values showed significant decrease, while MDA levels showed significant increase at the end of the $4^{\text {th }}$ and $8^{\text {th }}$ weeks as compared with control groups. These values were more pronounced at the end of $8^{\text {th }}$ than $4^{\text {th }}$ week in MP treated groups.

\section{I.1.D. Control Vs Sily + MP-treated groups :}

Data analysis revealed changes in the measured parameters in the form of significant decrease in SOD and GSH values accompanied with significant increase in MDA levels at the end of the $4^{\text {th }}$ and $8^{\text {th }}$ weeks in Sily+MP treated groups when compared with control groups. However, these changes were less marked at the end of the $8^{\text {th }}$ than the $4^{\text {th }}$ week in Sily+MP treated groups.

\section{I.1.E. Sily+MP Vs MP-treated groups :}

Statistical analysis revealed significant 
increase in SOD and GSH values as well as significant decrease in MDA levels in Sily+MP treated groups as compared with MP-treated groups at the end of $4^{\text {th }}$ and $8^{\text {th }}$ weeks.

\section{I.2 Liver and kidney functions assay parameters (Table 2) :}

The results of the present study showed non significant changes in liver function tests "AST, ALT, ALP" and kidney function tests, "BU, CRE" when vehicle and Sily treated groups were compared with control groups at the end of $4^{\text {th }}$ and $8^{\text {th }}$ weeks.

Data analysis of liver function tests showed a significant increase in MP and Sily+MP treated groups when compared with control group after 4 and 8 weeks of their administration. However, a significant decrease was found in Sily+MP treated groups as compared with MP treated groups at the end of $4^{\text {th }}$ and $8^{\text {th }}$ weeks. However, marked improvement in these parameters was seen at the end of $8^{\text {th }}$ than $4^{\text {th }}$ week in Sily+MP treated groups.

The results obtained from the effect of $\mathrm{MP}$ and Sily+MP treated groups on kidney function tests revealed significant increase as compared with those of control groups at the end of $4^{\text {th }}$ and $8^{\text {th }}$ weeks. On the other hand, BUN and CRE levels were significantly de-creased in Sily+MP treated groups as com-pared with MP treated groups at the end of $4^{\text {th }}$ and $8^{\text {th }}$ weeks. Also, marked improvement in these parameters was seen at the end of 8th than $4^{\text {th }}$ week in Sily+MP-treated groups.

\section{Liver Histopathological Results} (Figures 1-5):

The histological examination of hepatic tissues of the control groups as well as vehicle and Sily treated groups at the end of $4^{\text {th }}$ and $8^{\text {th }}$ weeks revealed normal hepatic architecture with cords of hepatocytes radiating from the central veins. The hepatocytes appeared polyhedral in shape with well defined boundaries and acidophilic cytoplasm. Each cell showed a round, vesicular, centrally located nucleus. The hepatic sinusoids appeared as narrow spaces lined by flattened endothelial cells and von kupffer cells.

Rats given MP for 4 weeks showed significant histopathological alterations in the form of single cell necrosis of hepatocytes, cloudy swelling, pyknotic and binucleate nucleus, ballooning of hepatocytes, and Kupffer cell proliferation. However, in Sily+MP treated group the previously men-tioned histopathological changes were less severe when compared with MP treated group.

At the end of $8^{\text {th }}$ week, the liver of MP treated rats showed higher incidence of the previously mentioned lesions than rats treated for 4 weeks with focal hepatic 
necrosis, central venous congestion, lymphocytic infiltrations, and hydropic degeneration. While, liver examination of rats treated with Sily+MP showed marked decrease in the incidence of all lesions when compared with MP treated group but did not return back to normal as compared with control group at both periods.

Histopathologic comparison of hepatotoxicity in Sily+MP treated groups at the end of the $4^{\text {th }}$ and $8^{\text {th }}$ weeks revealed marked decrease in all lesions severity at the end of $8^{\text {th }}$ week than $4^{\text {th }}$ week.

\section{Kidney Histopathological Results (Figures 6-10):}

Light microscopic examination of the kidney sections of control rats as well as vehicle and Sily treated rats at the end of $4^{\text {th }}$ and $8^{\text {th }}$ weeks showed normal renal cortical and medullary structures, which consist of glomerulus (tuft of blood capillaries surrounded by epithelial capsule, namely Bowman's capsule), proximal (formed of pyramidal cells with central round nucleus and acidophilic cytoplasm) and distal (contain cubical cells with epical round nucleus) convoluted tubules and the collecting tubules (lined with cubical columnar cells).

After 4 weeks of MP exposure, vascular dilatation, glomerular atrophy, cloudy swelling in cortical tubules, and few foci of hydropic degeneration were observed. While, 4 weeks after Sily+MP was given to rats, interstitial inflammatory cell infiltrations were detected and some of the renal tubules were dilated. In addition, 8 weeks after MP treatments to rats, hemorrhage, edema, necrosis, interstitial tissue infiltration by inflammatory cells, marked tubular dilatation, and glomerular atrophy were observed. While, 8 weeks after Sily+MP treatment to rats, calcification, tubular degeneration and mild mononuclear cell infiltration were reported. However, the incidence of all lesions were less marked in Sily+MP treated groups when compared with MP treated groups at the end of $4^{\text {th }}$ and $8^{\text {th }}$ weeks but still different when compared with control group.

Marked decrease in all kidney lesions was noticed at the end of $8^{\text {th }}$ week than $4^{\text {th }}$ week in Sily+MP treated groups.

\section{DISCUSSION}

Organophosphorous pesticides are among the most worldwide-used agrochemicals; are mainly known by their neurotoxic effects due to the inhibition of acetylcholinesterase by their oxygen analogues, which are the active metabolites generated during OP metabolism (Jokanovic, 2001). Acute and chronic toxicity studies indicate that MP is very highly toxic to mammals. Mammals are expected to be adversely affected by MP through 
oral, dermal and inhalation exposure pathways (Garcia et al., 2003).

It has been reported that OP compounds induce oxidative or toxic stress in animals and humans, both in acute and chronic poisonings (Ranjbar et al., 2002; Ghafour-Rashidi et al., 2007). These oxygen free radicals can be neutralized by a series of enzymatic systems (Siess, 1991). The two main physiological antioxidant defenses against free radicals are SOD and the glutathione system. Both these defence mechanisms are subjected to depletion during a period of toxic substance overload (Wellington and Jarvis, 2001).

In the present study, MP administration to rats resulted in oxidative stress which was manifested by significant decrease in the mean values of SOD and RGSH as well as significant increase in MDA levels when compared with control groups at the end of both experimental periods. However, pre-treatment with Sily supplementation resulted in modulation of these measured parameters (but still significantly different as compared with control groups at the end of both studied periods) as evidenced by significant decrease in MDA levels as well as significant increase in SOD activities and RGSH levels in Sily+MP treated groups as compared with MP treated groups at the end of the $4^{\text {th }}$ and $8^{\text {th }}$ weeks. Moreover, these parameters were markedly improved at the end of $8^{\text {th }}$ week than $4^{\text {th }}$ week in Sily+MP treated groups.

In accordance with the present work the studies done by Suke et al. (2008) and Celik and Suzek (2008) who reported significant increase in MDA levels as well as significant decrease in SOD activity (erythrocytes and lung) and GSH levels (in whole blood and various tissue homogenates) of rats exposed to MP.

Also, intra-peritoneal injection of MP into male rats showed significant decrease in erythrocyte SOD enzyme activity (Popovici et al., 2002). In addition, López et al. (2007) reported lower levels of erythrocyte SOD in farmers engaged in intensive agriculture area.

However, Celik and Suzek (2008) demonstrated significant increase in SOD activity in rats' erythrocytes. Doyotte et al. (1997) pointed out that a decreased enzyme activity' response may accompany a first exposure to pollutants, which can be followed by an induction of antioxidant systems. Thus, the existence of an inducible antioxidant system may reflect an adaptation of organisms. In contrast, Dimitrova et al. (1994) suggested that the superoxide radicals by themselves or after their transformation to $\mathrm{H}_{2} \mathrm{O}_{2}$ cause an oxidation of the cysteine in the enzyme and decrease SOD activity. Consequently, the decreased and increased SOD activities 
might have reflected a cellular oxidative stress due to MP exposure.

Della Morte et al. (1994) reported that exposure to the pesticides, including MP, may induce an alteration of natural mechanisms of defence against toxicants in mam-mals, including humans as evidenced by significant depletion of GSH in rat liver fractions. This finding is in agreement with the present study.

Arthur (2000) has reported that the overproduction of ROS may be associated with the depletion in the GSH level. These findings go hand in hand with that of Monteiro et al. (2006) who explained the mechanism of GSH depletion in tissue content after exposure to MP as being due to an increased utilization with subsequent conversion into oxidized glutathione as well as an inefficient GSH regeneration. Furthermore, Della Morte et al. (1994) concluded that MP was able to deplete GSH probably by forming GSH conjugates.

In accordance with the increase of MDA levels in the present work was the study done by Kalender et al. (2007) who reported an elevation of MDA levels, as measured in various tissue homogenates, after exposure to MP. In addition, subchronic oral administration of MP induced significant elevation of MDA as measured in rats' plasma (Guney et al., 2007). The increased MDA content might have resulted from an increase of free radicals as a result of stress condition in the rats with MP intoxication (Freeman and Crapo, 1981).

As an antioxidant, Sily and silibinin are probably able to antagonise the depletion of SOD and GSH by acting as free radical scavengers that reducing the free radical load, increasing GSH levels and stimulating SOD activity and/or expression (Wellington and Jarvis, 2001). Data of the present work are in agreement with these findings.

As an anti-lipoperoxidation, Sily displayed protection against the toxicity of some pro-oxidant agents that can significantly stimulate the activity of thiobarbituric acid reactive substance (a wellestablished assay for screening and monitoring LPO). For example, Sily can reverse LPO induced by paracetamol (Nencini et al., 2007). The protective effect of Sily against LPO formation and elevation of MDA may be mediated by its antioxidative capacity to scavenge free radicals (Mira et al., 1994). These findings go hand in hand with the present study.

Data obtained from the present study showed that rats treated with MP and Sily+MP were associated with hepatotoxic and nephrotoxic pictures as evidenced by 
significant changes in liver and kidney biochemical enzymes as well as hepatic and renal histopathological architecture, respectively, when compared with control groups at the end of $4^{\text {th }}$ and $8^{\text {th }}$ weeks. These changes were less marked in Sily+MP treated groups in comparison with MP treated groups at the end of both tested periods. In addition, both biochemical and histopathological changes were less marked at the end of $8^{\text {th }}$ week than $4^{\text {th }}$ week in Sily+MP treated groups.

The action of the toxins on the liver and kidney might alter the enzyme activity (Dikshith et al. 1975). Also, histopathological changes were mostly confined to organs directly involved in pesticide metabolism and detoxification (Rashatwar and Ilyas, 1984). The radiolabel MP was detected in many guinea pigs and rats' tissues, among which the liver and kidney had the highest radioactivity (Miyamoto, 1964).

Numerous experimental studies in rats showed liver and kidney injuries that were induced by MP as evidenced by biochemical alterations of liver (decreased plasma protein as well as increased AST and ALP levels) and kidney (increased BUN and protein in the urine) function tests (Bomhard et al., 1981). Also, toxic exposure to OP parathion (Gallo and Lawryk, 1991) produced elevation of liver and kidney serum enzymes. Several other studies have demonstrated raised liver enzymes (Hernández et al., 2006) and kidney enzymes (Attia, 2006) in farmers as well as agricultural workers occupationally exposed to pesticides. The pronounced increases in the liver enzymatic activities induced by exposure to MP are indicative of the cellular toxicity of this compound even after its subchronic administration in low doses for a long period (Kaur and Dhanju, 2004). The cause of this rise in liver enzymes can be due to its effect on liver, muscle and/or heart (Golbs et al., 1978). These findings go hand in hand with the present results.

Dikshith et al. (1991), found that the toxicity of repeated dermal applications of MP to rats induced degenerative changes in the liver and kidney. Also, liver and kidney lesions were reported in humans dying of acute MP (Wofatox) intoxication as confirmed by histopathological examination. This may be a secondary effect of hypoxia related to the neurologic effects of MP on vascular smooth muscle and on the electrical conduction system of the heart (Fazekas, 1971). In addition, rats treated with MP for 7 weeks showed higher renal histopathological changes than those treated for 4 weeks (Kalender et al., 2007).

On the contrary, adult male rats exposed to MP daily under the skin showed 
slight non significant decrease in plasma ALT concentration. In addition, postmortem quantification of total proteins and triglycerides in the hepatic tissue confirm a normal hepatic function. Additionally, the mean values of CRE concentrations in plasma and urine did not demonstrate any significant differences in treatment groups as compared to those of controls (Castillo et al., 2002). Also, histopathological examination of the liver and kidney from birds (Solecki et al., 1996) and renal system of mice or rats (NCI, 1979) exposed to MP in the diet showed no morphological changes. Paw-owska et al. (1990-1991) stated that changes in the activities of serum liver enzymes depend on the dose of pesticides given to rats. Also, the greater the degree of pesticide exposure the higher would be the levels of liver enzymes (Yavuz et al., 2007).

Pesticide exposure causes leakage of cytosolic enzymes from hepatocytes and other body organs (Dewan et al., 2004). A single dermal dose of MP caused significant inhibition of liver butyrylcholinesterase activity (Abu-Qare et al., 2001). The increased acetylcholine leads to vascular disturbance with vasogenic edema and hepatocellular damage. This may explain the elevated levels of AST and ALT after leakage of these enzymes from the liver cells into the blood. Also, swelling and edema of hepatocytes cause partial obstruction of bile canaliculi with subsequent elevation of ALP level, which reflects cholestatic injury (El Ghawaby et al., 1996). Also, the metabolic pathway of MP leads to a state of oxidative stress with subsequent production of peroxides and free radicals that damage all the components of the cell, including protein, lipids, DNA and RNA. In addition to damaging macromolecules, ROS influence molecular and biochemical processes and disrupts the function of DNA repair proteins (Martignoni et al., 1999).

Various studies suggested that both renal circulation and electrolytes excretion were under partial cholinergic control and thus exposure to cholinesterase inhibitors may disrupt normal renal function. Indeed, it has been shown that OP poisoning often led to pathophysiological damage in the kidney. Also, the lipophilicity of OPs may allow their penetration through plasma membranes with direct access to the intracellular space and organelles, thus rendering kidney cells susceptible to their toxic effects (Bloch-Shilderman and Levy, 2007).

Sily-treated rats in the present study showed more pronounced increases in SOD and GSH values as well as more pronounced decrease in MDA levels at the end of $8^{\text {th }}$ week than $4^{\text {th }}$ week when compared with control groups. Administra- 
tion of Sily $(100 \mathrm{mg} / \mathrm{kg})$ alone to healthy rats for 8 weeks showed increase in serum and hepatic SOD activity (Xing and $\mathrm{He}$, 2007). Additionally, it increases the redox state and the total glutathione in the liver by more than $35 \%$ and $50 \%$ in healthy subjects and rats, respectively (Valenzuela et al., 1989). Furthermore, mice fed milk thistle seed oil showed increase in body weight without any microscopic pathologic changes in their livers and kidneys (Khan et al., 1986). These findings are in agreement with the present work.

Sily has been used for decades as herbal remedy and as a hepato-protectant in therapy of acute and chronic liver diseases (Gazak et al., 2007). As a hepatoprotectant, Sily showed significant protection against anti-tuberculosis drugs induced hepatotoxicity, as evidenced by marked reduction of the raised serum markers of hepatic function (Tasduq et al., 2005).

Moreover, numerous studies in rodents have shown that Sily provides protection against the toxicity of wide range of hepatotoxins. For example, Sily protects against liver lesions induced by $\mathrm{CCl} 4$ (Muriel and Mourelle, 1990) and lindane (Szpunar et al., 1976).

Milk thistle's effects on the kidney closely mirror the herb's effects on the liver (Abascal and Yarnell, 2003). As a nephro-protectant, Sily and / or silibinin (the main constituent of Sily) showed protective or preventive effects against nephrotoxicity in rats induced by different offending agents. Sily can prevent pathological renal damage and/or renal biochemical enzymatic alternations induced by cisplatin (Gaedeke et al., 1996), and gentamicin (Varzi et al., 2007).

Sily is incorporated in cell membranes and increases the resistance of the membranes against injurious influences, probably by changing the physiochemical properties. It prevents the uptake of the mushroom toxins amanitin and phalloidin by competitive inhibition of receptors at the outer cell membrane and protects the liver against poisoning by organophosphate insecticides. It also stimulates RNA polymerase A, polymerase I, which enhances ribosome protein synthesis and activates the regenerative capacity of the liver cells. Silibinin has been used on laboratory rats to protect them from glomerular and tubular damage from cisplatin. Milk thistle prevents liver damage from butyrophenones, phenothiazines, acetaminophen, halothane, dilantin and ethanol due to membrane-stabilizing and free radical scavenging effects of Sily (Tilgner, 1999). Thus, Sily acts by antioxidative, antilipid peroxidative, antifibrotic, antiinflammatory, membrane stabilizing, 
immunomodulatory and liver regenerating mechanisms. Also, it promotes protein synthesis, enhances glucuronidation and protects against glutathione depletion (Pradhan and Girish, 2006).

In summary, rats exposed to MP showed marked oxidative stress as well as liver and kidney injuries that were pronounced at the end of the $8^{\text {th }}$ week. Periodical measurement of liver and kidney function tests are required for early detection of both organs impairment in workers engaged with OPC. Pretreatment with Sily provided protective or ameliorative effects against these toxicities. Thus, Sily possess a good hepato- and nephroprotectant properties and might be used as a detoxifying agents in workers chronically exposed to OPC.

\section{Acknowledgement:}

The technical assistance of Prof. Dr. Taghreed A. Abd El Azez, Assistant Prof. of Pathology, Faculty of Medicine, Benha University, is deeply appreciated. 
Table (1): The effects of Corn oil, Silymarin, MP, and Sily + MP on MDA levels, RGSH and SOD activities, as compared with control, after 4 and 8 weeks of their oral administration to 10 normal adult male rats.

\begin{tabular}{|c|c|c|c|c|}
\hline \multicolumn{2}{|c|}{ Group A (4 Weeks) } & $\begin{array}{c}\text { MDA } \\
(\mathrm{nmol} / \mathrm{ml})\end{array}$ & $\begin{array}{l}\text { SOD } \\
(\mathrm{u} / \mathrm{ml})\end{array}$ & $\begin{array}{c}\text { RGSH } \\
(\mathrm{mg} / \mathrm{dl})\end{array}$ \\
\hline \multirow{2}{*}{ Control } & Mean & 2.9500 & 231.30 & 31.44 \\
\hline & $\mathrm{SD}$ & 0.1690 & 9.84 & 1.8682 \\
\hline \multirow{4}{*}{ Corn oil } & Mean & 2.9640 & 234.80 & 31.13 \\
\hline & $\pm \mathrm{SD}$ & 0.1890 & 5.65 & 1.5171 \\
\hline & $\mathrm{P}$ & $>0.40$ & $>0.15$ & $>0.30$ \\
\hline & Sig. & NS & NS & NS \\
\hline \multirow{4}{*}{ Sily } & Mean & 2.7000 & 241.6 & 32.94 \\
\hline & $\pm \mathrm{SD}$ & 0.3127 & 8.83 & 0.8861 \\
\hline & $\mathrm{P}$ & $<0.025$ & $<0.0125$ & $<0.025$ \\
\hline & Sig. & $*$ & $*$ & $*$ \\
\hline \multirow{4}{*}{ MP } & Mean & 4.5550 & 201.50 & 29.49 \\
\hline & $\pm \mathrm{SD}$ & 0.4814 & 9.10 & 1.0553 \\
\hline & $\mathrm{P}$ & $<0.0005$ & $<0.0005$ & $<0.01$ \\
\hline & Sig. & $* * *$ & $* * *$ & $* *$ \\
\hline \multirow{4}{*}{ Sil+MP } & Mean & 3.40 & 218 & 29.33 \\
\hline & $\pm \mathrm{SD}$ & 0.5204 & 9.65 & 0.9158 \\
\hline & $\mathrm{P}$ & $<0.10$ & $<0.005$ & $<0.0025$ \\
\hline & Sig. & $* *$ & $* *$ & $* *$ \\
\hline \multirow{2}{*}{ Sily+MP Vs MP } & $\mathrm{P}$ & $<0.0005$ & $<0.0005$ & $<0.0005$ \\
\hline & Sig. & $* * *$ & $* * *$ & $* * *$ \\
\hline \multicolumn{2}{|c|}{ Group B (8 Weeks) } & $\begin{array}{c}\text { MDA } \\
(\mathrm{nmol} / \mathrm{ml})\end{array}$ & $\begin{array}{c}\text { SOD } \\
(\mathrm{u} / \mathrm{ml})\end{array}$ & $\begin{array}{c}\text { RGSH } \\
(\mathrm{mg} / \mathrm{dl})\end{array}$ \\
\hline \multirow{2}{*}{ Control } & Mean & 3.0170 & 233.50 & 31.32 \\
\hline & $\pm \mathrm{SD}$ & 0.5451 & 8.24 & 1.8839 \\
\hline \multirow{4}{*}{ Corn oil } & Mean & 2.9150 & 236.80 & 31.96 \\
\hline & $\pm \mathrm{SD}$ & 0.4099 & 7.11 & 1.0049 \\
\hline & $\mathrm{P}$ & $>0.30$ & $>0.15$ & $>0.15$ \\
\hline & Sig. & NS & NS & $\mathrm{NS}$ \\
\hline \multirow{4}{*}{ Sily } & Mean & 2.54 & 247.30 & 33.16 \\
\hline & $\pm \mathrm{SD}$ & 0.2162 & 7.62 & 0.8573 \\
\hline & $\mathrm{P}$ & $<0.01$ & $<0.0025$ & $<0.01$ \\
\hline & Sig. & $* *$ & $* *$ & $* *$ \\
\hline \multirow{4}{*}{ MP } & Mean & 5.1750 & 175.50 & 26.35 \\
\hline & $\pm \mathrm{SD}$ & 0.5946 & 13.84 & 1.7549 \\
\hline & $\mathrm{P}$ & $<0.0005$ & $<0.0005$ & $<0.0005$ \\
\hline & Sig. & $* * *$ & $* * *$ & *** \\
\hline \multirow{4}{*}{ Sily+MP } & Mean & 3.507 & 225.4 & 29.97 \\
\hline & $\pm \mathrm{SD}$ & 0.3084 & 7.93 & 0.5251 \\
\hline & $\mathrm{P}$ & $<0.0125$ & $<0.025$ & $<0.025$ \\
\hline & Sig. & $*$ & $*$ & $*$ \\
\hline \multirow{2}{*}{ Sily+MP Vs MP } & $\mathrm{P}$ & $<0.0005$ & $<0.0005$ & $<0.0005$ \\
\hline & Sig. & $* * *$ & $* * *$ & $* * *$ \\
\hline
\end{tabular}

$\mathrm{P}>0.05=$ non-significant; $\mathrm{P}<0.05=$ significant; $\mathrm{NS}=$ non-significant 
Khodeary et al ...

Table (2): The effects of Corn oil, Silymarin, MP, and Sily + MP on liver and kidney function tests, as compared with control, after 4 and 8 weeks of their oral administration to 10 normal adult male rats.

\begin{tabular}{|c|c|c|c|c|c|c|}
\hline \multicolumn{2}{|c|}{ Group A (4 Weeks) } & $\begin{array}{c}\mathbf{A L T} \\
\mathbf{u} / \mathbf{l}\end{array}$ & $\begin{array}{c}\text { AST } \\
\mathbf{u} / \mathbf{l}\end{array}$ & $\begin{array}{c}\mathbf{A L P} \\
\mathbf{u} / \mathbf{l}\end{array}$ & $\begin{array}{l}\text { BUN } \\
\mathrm{mg} / \mathrm{dl}\end{array}$ & $\begin{array}{c}\text { CRE } \\
\mathrm{mg} / \mathrm{dl}\end{array}$ \\
\hline \multirow{2}{*}{ Control } & Mean & 33.14 & 36.58 & 97.36 & 34.12 & 0.85 \\
\hline & $\pm \mathrm{SD}$ & 5.63 & 5.88 & 17.04 & 6.20 & 0.21 \\
\hline \multirow{4}{*}{ Corn oil } & Mean & 36.84 & 39.02 & 99.67 & 35.31 & 0.91 \\
\hline & $\pm \mathrm{SD}$ & 5.95 & 6.67 & 15.46 & 6.86 & 0.24 \\
\hline & $\mathrm{P}$ & $>0.05$ & $>0.15$ & $>0.35$ & $>0.30$ & $>0.25$ \\
\hline & Sig. & NS & NS & $\mathrm{NS}$ & NS & NS \\
\hline \multirow{4}{*}{ Sily } & Mean & 32.34 & 35.29 & 98.87 & 32.46 & 0.87 \\
\hline & $\pm \mathrm{SD}$ & 5.57 & 5.19 & 16.13 & 7.24 & 0.23 \\
\hline & $\mathrm{P}$ & $>0.35$ & $>0.30$ & $>0.40$ & $>0.25$ & $>0.40$ \\
\hline & Sig. & NS & NS & NS & NS & NS \\
\hline \multirow{4}{*}{ MP } & Mean & 84.55 & 92.36 & 196.12 & 88.76 & 2.32 \\
\hline & $\pm \mathrm{SD}$ & 24.13 & 26.63 & 29.92 & 25.74 & 0.41 \\
\hline & $\mathrm{P}$ & $<0.0005$ & $<0.0005$ & $<0.0005$ & $<0.0005$ & $<0.0005$ \\
\hline & Sig. & $* * *$ & $* * *$ & $* * *$ & $* * *$ & $* * *$ \\
\hline \multirow{4}{*}{$\mathrm{Sil}+\mathrm{MP}$} & Mean & 40.23 & 44.91 & 121.27 & 43.67 & 1.21 \\
\hline & $\pm \mathrm{SD}$ & 5.34 & 6.86 & 18.28 & 7.18 & 0.31 \\
\hline & $\mathrm{P}$ & $<0.005$ & $<0.005$ & $<0.005$ & $<0.005$ & $<0.005$ \\
\hline & Sig. & $* *$ & $* *$ & $* *$ & $* *$ & $* *$ \\
\hline \multirow{2}{*}{ Sily+MP Vs MP } & $\mathrm{P}$ & $<0.0005$ & $<0.0005$ & $<0.0005$ & $<0.0005$ & $<0.0005$ \\
\hline & Sig. & $* * *$ & $* * *$ & $* * *$ & $* * *$ & $* * *$ \\
\hline \multicolumn{2}{|c|}{ Group B (8 Weeks) } & $\begin{array}{c}\text { ALT } \\
\mathbf{u} / \mathbf{l}\end{array}$ & $\begin{array}{c}\mathbf{A S T} \\
\mathrm{u} / \mathbf{l} \\
\end{array}$ & $\begin{array}{c}\mathbf{A L P} \\
\mathbf{u} / \mathbf{l} \\
\end{array}$ & $\begin{array}{l}\text { BUN } \\
\mathrm{mg} / \mathrm{dl}\end{array}$ & $\begin{array}{c}\text { CRE } \\
\mathrm{mg} / \mathrm{dl}\end{array}$ \\
\hline \multirow{2}{*}{ Control } & Mean & 35.82 & 38.56 & 112.67 & 36.47 & 0.97 \\
\hline & $\pm \mathrm{SD}$ & 7.49 & 7.97 & 23.18 & 7.62 & 0.25 \\
\hline \multirow{4}{*}{ Corn oil } & Mean & 36.23 & 38.06 & 114.12 & 37.32 & 0.96 \\
\hline & $\pm \mathrm{SD}$ & 8.17 & 7.12 & 23.85 & 8.03 & 0.26 \\
\hline & $\mathrm{P}$ & $>0.45$ & $>0.40$ & $>0.40$ & $>0.40$ & $>0.45$ \\
\hline & Sig. & NS & $\mathrm{NS}$ & NS & $\mathrm{NS}$ & NS \\
\hline \multirow{4}{*}{ Sily } & Mean & 34.41 & 37.44 & 109.63 & 35.71 & 0.92 \\
\hline & $\pm \mathrm{SD}$ & 7.82 & 7.36 & 24.06 & 7.71 & 0.20 \\
\hline & $\mathrm{P}$ & $>0.30$ & $>0.35$ & $>0.35$ & $>0.40$ & $>0.30$ \\
\hline & Sig. & NS & NS & NS & NS & NS \\
\hline \multirow{4}{*}{ MP } & Mean & 138.12 & 157.69 & 298.50 & 178.57 & 4.58 \\
\hline & $\pm \mathrm{SD}$ & 32.32 & 33.46 & 56.45 & 34.91 & 0.66 \\
\hline & $\mathrm{P}$ & $<0.0005$ & $<0.0005$ & $<0.0005$ & $<0.0005$ & $<0.0005$ \\
\hline & Sig. & $* * *$ & $* * *$ & $* * *$ & $* * *$ & $* * *$ \\
\hline \multirow{4}{*}{$\mathrm{Sil}+\mathrm{MP}$} & Mean & 45.78 & 47.87 & 136.98 & 59.07 & 1.34 \\
\hline & $\pm \mathrm{SD}$ & 12.21 & 13.66 & 30.48 & 14.14 & 0.41 \\
\hline & $\mathrm{P}$ & $<0.025$ & $<0.05$ & $<0.05$ & $<0.0125$ & $<0.0125$ \\
\hline & Sig. & $*$ & $*$ & $*$ & $*$ & $*$ \\
\hline \multirow{2}{*}{ Sily+MP Vs MP } & $\mathrm{P}$ & $<0.0005$ & $<0.0005$ & $<0.0005$ & $<0.0005$ & $<0.0005$ \\
\hline & Sig. & $* * *$ & $* * *$ & $* * *$ & $* * *$ & $* * *$ \\
\hline
\end{tabular}

$\mathrm{P}>0.05=$ non-significant; $\mathrm{P}<0.05=$ significant; $\mathrm{NS}=$ non-significant 


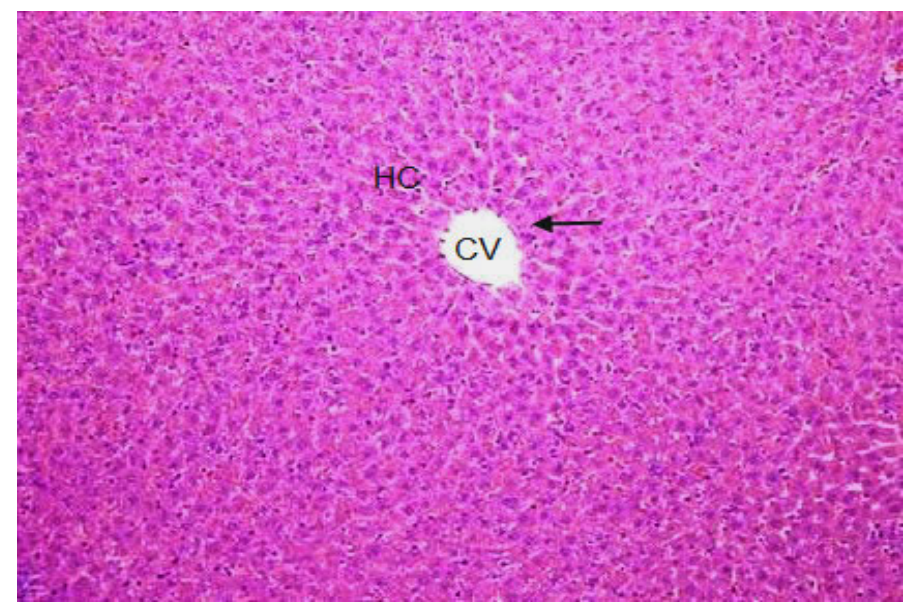

Fig. (1) : Liver section obtained from control group showing cords of hepatocytes (HC) radiating from central vein $(\mathrm{CV})$ and normal blood sinusoids (ii). \{Original Magnification, OMx100\}

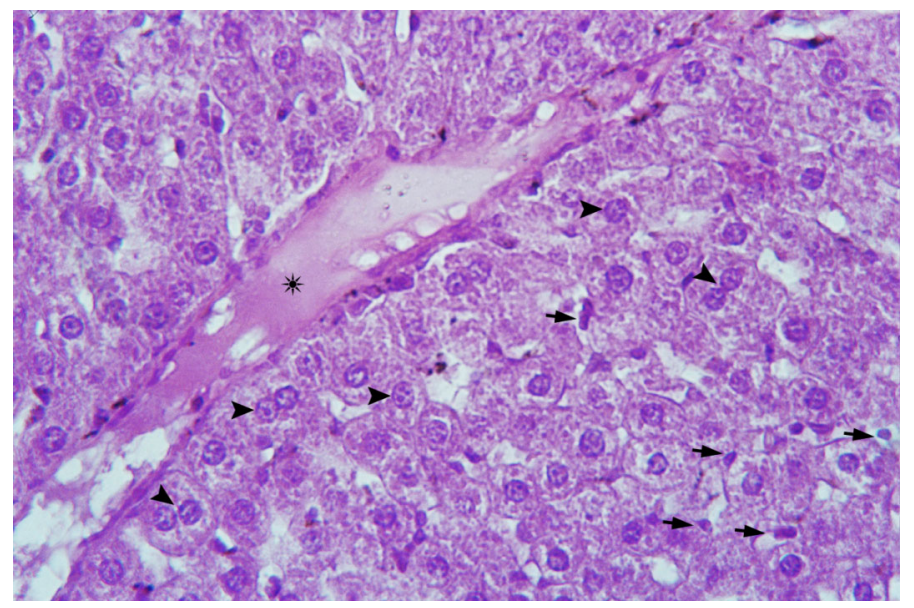

Fig. (2) : Liver section obtained from MP treated group after 4 weeks showing ballooning of $\mathrm{HC}$, dilated lymph channel with transudate (Ô), binucleated nucleus with clumped nuclear chromatin (ن̈), pyknotic nuclei ( $\tilde{\mathrm{n}}) .\{\mathrm{OMx} 400\}$

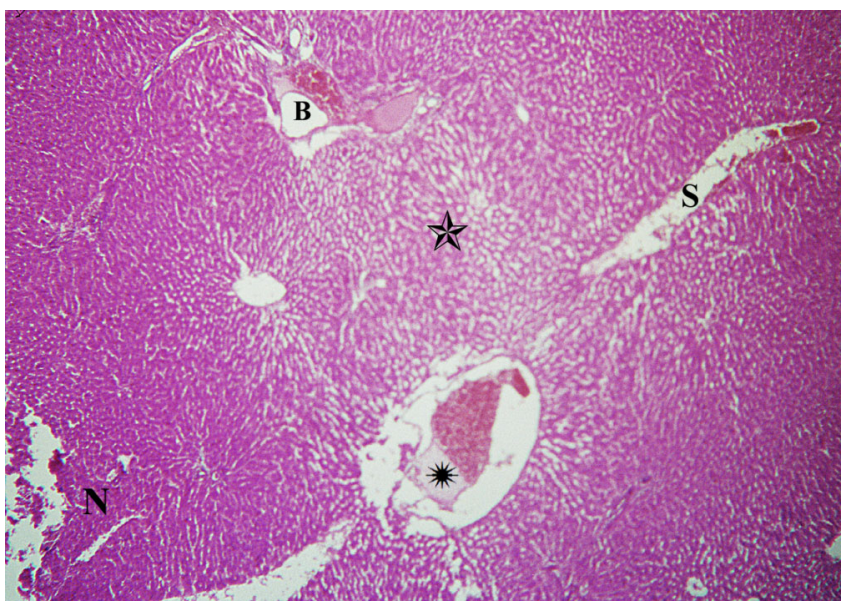

Fig. (3) : Liver section obtained from MP treated group after 8 weeks showing necrosis $(\mathrm{N})$, hydropic degeneration ( $\hat{\mathrm{U}}), \mathrm{CV}$ congestion (Ô), dilated vascular sinusoid (S), and bile duct proliferation (B). $\{\mathrm{OMx} 100\}$ 


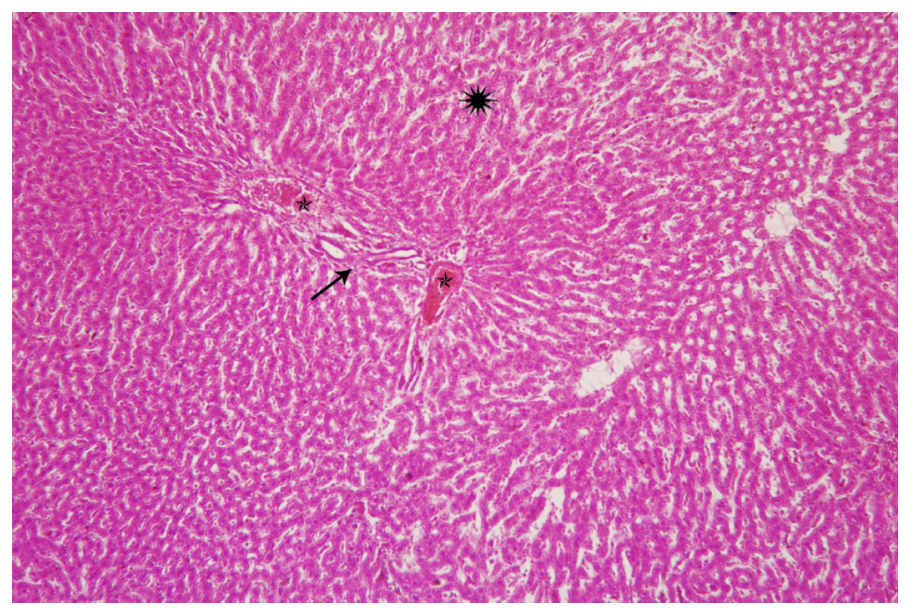

Fig. (4) : Liver section obtained from Sily+MP treated group after 4 weeks showing dilated sinusoid (Ô), mild degeneration of $\mathrm{HC}$, bile duct proliferation (è), and CV congestion (U).$\{\mathrm{OMx} 100\}$

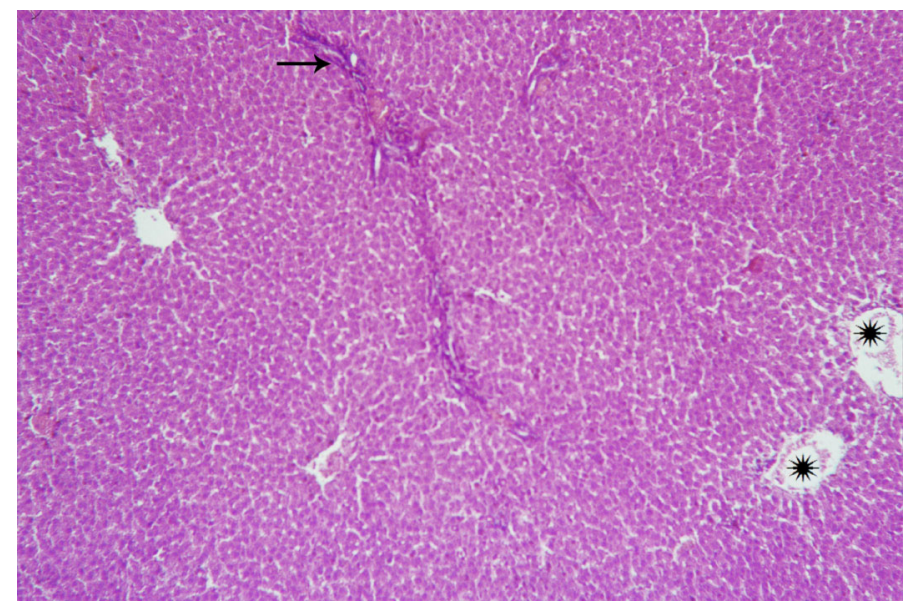

Fig. (5) : Liver section obtained from Sily+MP treated group after 8 weeks showing nearly normal appearance of HC with lymphocytic infiltration (è) and mild CV congestion (Ô). $\{\mathrm{OMx} 100\}$

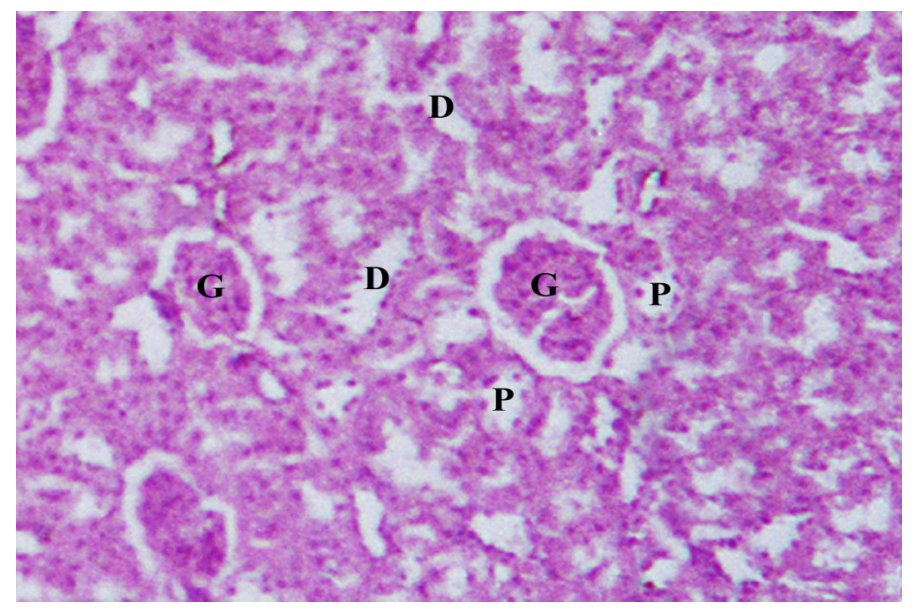

Fig. (6) : Kidney section obtained from control group showing normal renal corpuscle (glomeruli and Bowman's space) (G), proximal (P) and distal (D) convoluted tubules. $\{\mathrm{OMx} 200\}$ 


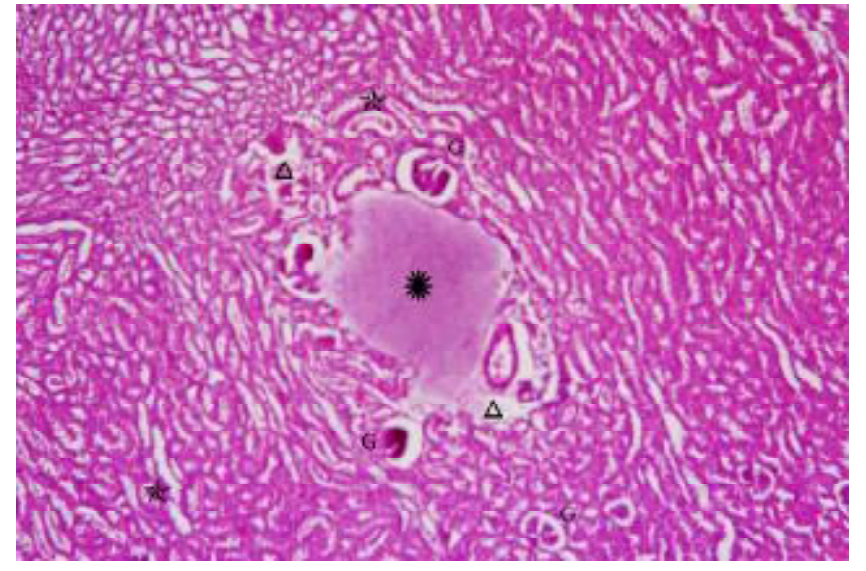

Fig. (7) : Kidney section obtained from MP treated group after 4 weeks showing atrophic glomeruli with widening of Bowman's space $(\mathrm{G})$, dilated atrophic tubules ( $\hat{\mathrm{U}})$, dilated blood vessel (w) with transudate (Ô). $\{\mathrm{OMx} 100\}$

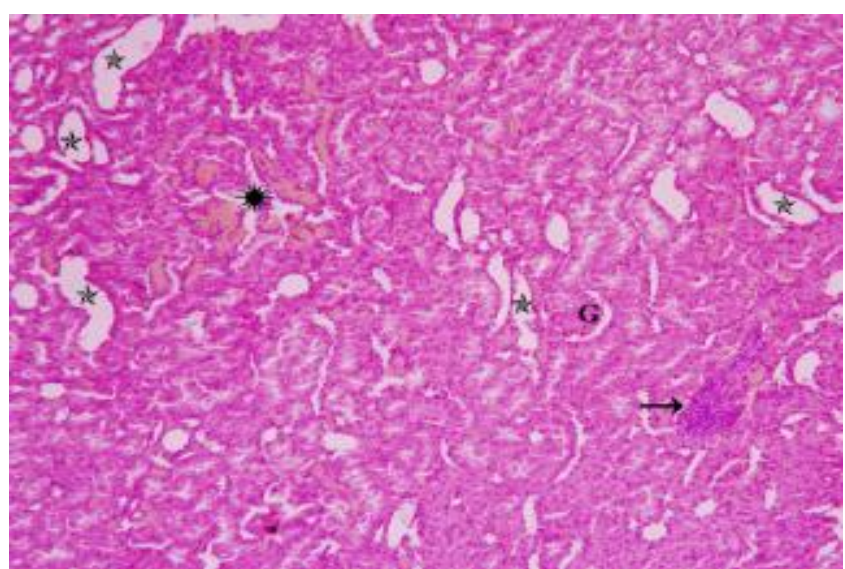

Fig. (9) : Kidney section obtained from Sily+MP treated group after 4 weeks showing less dilated tubules (Û), mild hydropic degeneration of tubular cells, lymphocytic infiltration (è), minimal hemorrhage (Ô), and nearly normal glomeruli $(\mathrm{G})$. (OMx100)

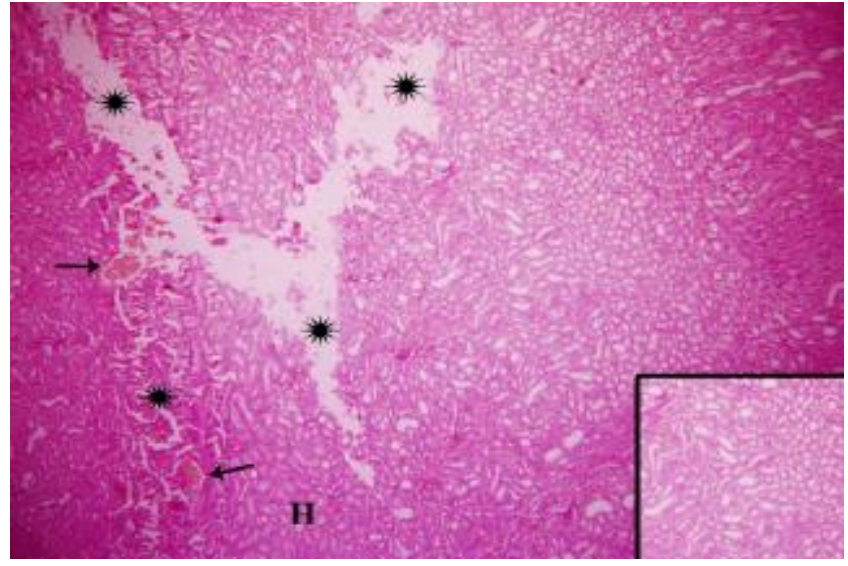

Fig. (8) : Kidney section obtained from MP treated group after 8 weeks showing necrosis (Ô), dilated blood vessels (è), hydropic degeneration $(\mathrm{H})$, and dilated atrophic tubules (inset). $\{\mathrm{OMx} 100\}$

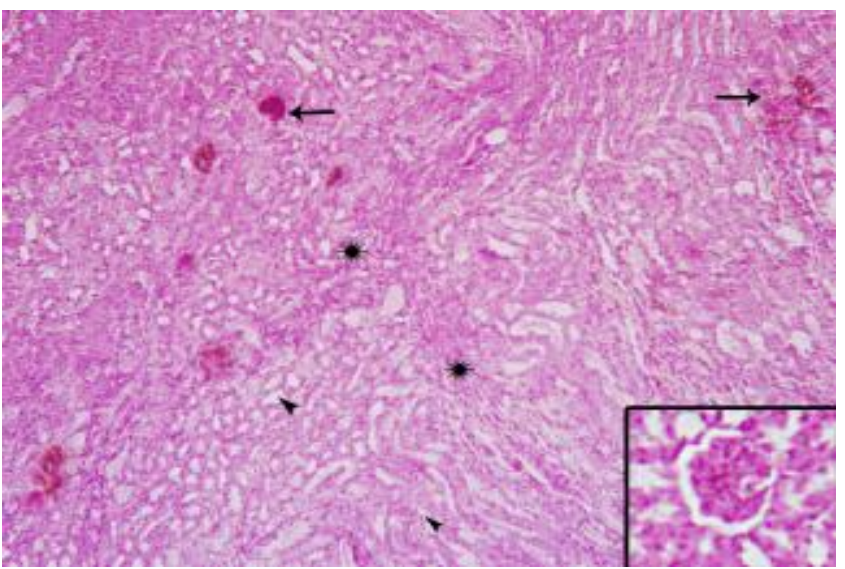

Fig. (10) : Kidney section obtained from Sily+MP treated group after 8 weeks showing inflammatory cells infiltration (Ô), tubular degeneration ( $\ddot{U})$, macro calcifications (è), and nearly normal glomerulus. $\{\mathrm{OMx} 100\}$ 


\section{REFERENCES}

Abascal, K. and Yarnell, E. (2003) : "The many faces of Silybum marianum (milk thistle), part 1". Altern. Complement. Ther., 9: 170-175.

Abdollahi, M.; Ranjbar, A.; Shadnia, S.; et al. (2004) : "Insecticides and oxidative stress : A review". Med. Sci. Monit., 10 : RA141-RA147.

Abu-Qare, A. W.; Abdel-Rahman, A.; Brownie, C.; et al. (2001) : "Inhibition of cholinesterase enzymes following a single dermal dose of chlorpyrifos and methyl parathion, alone and in combination, in pregnant rats". J. Toxicol. Environ. Health, 63: 173-189.

Arthur, J. R. (2000) : "The glutathione peroxidases". Cell Mol. Life Sci., 57 : 18251835.

Aslan, R.; Sekeroglu, M. R.; Tarakçioglu, M.; et al. (1997) : “Investigation of malondialdehyde formation and antioxidant enzyme activity in stored blood". Haematologia (Budap), 28: 233-237.

ATSDR (Agency for Toxic Substances and Disease Registry) (2001) : Toxicological Profile For Methyl Parathion. Atlanta, Georgia, USA, September.

Attia, M. A. (2006) : “Risk assessment of occupational exposure to pesticides". Earth Environ. Sci., 3 : 349-362.

Bloch-Shilderman, E. and Levy, A (2007) : "Transient and reversible nephrotoxicity of sarin in rats". J. Appl. Toxicol., 27: 189-194.

Bomhard, E.; Loser, E. and Schilde, B. (1981) : E605-methyl (Parathion -methyl), chronic toxicological study on rats. Bayer AG. Study No. 9889. DPR Vols. 121-051, 052, 063; \#37188, 37189, \#074202. Adapted From: Cal/EPA (2004): Methyl Parathion, Risk Characterization Document, Dietary and Ambient Air Exposures. Koshlukova SE, Reed NR, Silva MH, Gee JF, Pfeifer K, and Schreider JP (Contributors). California Environmental Protection Agency, Department of Pesticide Regulation, Medical Toxicology Branch (October 26, 2004).

Castillo, C. G.; Montante, M.; Dufour, L.; et al. (2002) : "Behavioral effects of exposure to endosulfan and methyl parathion in adult rats. Neurotoxicol". Teratol., 24: 797-804.

Celik, I. and Suzek, H. (2008) : "Subacute effects of methyl parathion on antioxidant defense systems and lipid peroxidation in rats". Food Chem. Toxicol., 46: 2796-2801.

Comoglio, L.; Amin, O.; Roque, A.; et al. (2005) : "Evaluation of sublethal bio- 
markers in litopenaeus vannamei on food born exposure to methyl parathion". Ecotoxicol. Environ. Saf., 62: 66-67.

Crocenzi, F. A.; Sanchez Pozzi, E. J.; Pellegrino, J. M; et al. (2003) : "Preventive effect of silymarin against taurolithocholate-induced cholestasis in the rat". Biochem. Pharmacol., 66: 355-364.

Cuschieri, A. and Backer, P. P. (1977) : Introduction to Research in Medical Science. Churchill Livingstone Edinburgh, London, New York, P.16.

Dalmi, L. and Sari, B. (1992) : “The effect of silibinin on the free radical scavenger mechanisms of human erythrocytes in vitro". Acta Physiol. Hung., 80: 375-380.

Della Morte, R.; Villani, G. R.; Di Martino, E.; et al. (1994) : “Glutathione depletion induced in rat liver fractions by seven pesticides". Boll. Soc. Ital. Biol. Sper., 70 : 185-192.

Dewan, A.; Bhatnager, V. K.; Mathur, M. L.; et al. (2004) : "Repeated episodes of endosulphan poisoning". Clini. Toxicol., 42: 4363-4369.

Dikshith, T. S.; Behari, J. R.; Datta, F. K. and Mathur, A. K. (1975) : “Effect of diazinon in male rats. Histopathological and biochemical studies". Environ. Physiol. Biochem., 5: 293-299.
Dikshith, T. S.; Raizada, R. B.; Singh, V.; et al. (1991) : "Repeated dermal toxicity of technical $\mathrm{HCH}$ and methyl parathion (50EC) to female rats (Rattus norvigicus)". Indian J. Exp. Biol., 29: 149-155.

Dimitrova, M. S. T.; Tsinova, V. and Velcheva, V. (1994) : “Combined effect of zinc and lead on the hepatic superoxide dismutase-catalase system in carp (Cyprinus carpio)". Comp. Bio-chem. Physiol., 108: 43-46.

Donald, W. M. and Ralph, H. (1993) : Methods of alkaline phosphatase activity and aminotransferase. In: Tietz Textbook of Clinical Chemistry. $2^{\text {nd }}$ ed., WB Saunders Co., London, P.P. 788:832.

Doyotte, A.; Cossu, C.; Jacquin, M. C.; et al. (1997) : "Antioxidant enzymes glutathione and lipid peroxidation as relevant biomarkers of experimental or field exposure in the gills and the digestive gland of the freshwater bivalve Unio tumidus". Aquat. Toxicol., 39: 93-110.

Drury, R. A. and Wallington, E. A. (1980) : Carleton's Histological techniques. Oxford Univ. Press, London, $5^{\text {th }}$ ed., P.P. 241-242.

Eddleston, M. (2000) : "Patterns and problems of deliberate self-poisoning in developing world". QJM, $93: 715$ 731. 
El-Ghawaby, F. A.; El-Kolaly, H. R. and Hashem, N. A. (1996) : "Structural and enzymatic study on the effect of anticholinesterases on rabbit's liver". Sc. J. Az. Med. Fac. (Girls), 17 (2): 323-335.

Fazekas, G. I. (1971) : "Macroscopic and microscopic changes in Wofatox (methyl parathion) poisoning". Zeitschift fur Rechtsmedizin, 68: 189-194.

Frankel, A. and Gradwohl, E. C. (1970) : "A colorimetric method for determination of serum transaminases". Am. J. Clin. Path., 28 : 26-34.

Freeman, B. A. and Crapo, J. D. (1981): "Hyperoxia increases oxygen radical production in rat lung and lung mitochondria". J. Biol. Chem., 256: 10986-10992.

Gaedeke, J.; Fels, L. M.; Bokemeyer, C.; et al. (1996) : "Cisplatin nephrotoxicity and protection by silibinin". Nephrol. Dial. Transplant, 11: 55-62.

Gallo, M. A. and Lawryk, N. J. (1991) : Organic phosphorus pesticides. In: Pesticides Studied in Man. Hayes, W. J.; Laws, (Eds.), Ch. 16, Williams \& Wilkins, Baltimore, P.P. 917-1123.

Garcia, S. J.; Abu-Qare, A. W.; MeekerO'Connell, W. A.; et al. (2003) : "Methyl Parathion : A review of health effects". J. Toxicol. Env. Heal., B6: 185-210.
Gazak, R.; Walterova, D. and Kren, V. (2007) : "Silybin and silymarin-new and emerging applications in medicine". Curr. Med. Chem., 14: 315-338.

\section{Ghafour-Rashidi, Z.; Dermenaki-} Farahani, E.; Aliahmadi, A.; et al. (2007) : "Protection by cAMP and cGMP phosphodiesterase inhibitors on diazinon-induced hyperglycemia and oxidative/nitrosative stress in rat Langerhans islets cells: Molecular evidence for involvement of noncholinergic mechanisms". Pesticide Biochem. Physiol., 87: 261-270.

Golbs, S.; Fuchs, V.; Leipner, E.; et al. (1978) : "The effect of pesticide combinations in laboratory rats. III. Modification of selected enzymes". Arch. Exp. Veterinarmed, 32: 569-577.

Gultekin, F.; Ozturk, M. and Akdogan, M. (2000) : "The effect of organophosphate insecticide chlorpyrifos-ethyl on lipid peroxidation and antioxidant enzymes (in vitro". Arch. Toxicol., 74: 533-538.

Guney, M.; Oral, B.; Demirin, H.; et al. (2007) : "Fallopian damage induced by organophosphate insecticide methyl parathion, and protective effect of vitamins $E$ and $C$ on ultrastructural changes in rats". Toxicol. Ind. Health, 23: 429-438.

Hernández, A. F.; Amparo Gómez, M.; Pérez, V.; et al. (2006) : "Influence of expo- 
sure to pesticides on serum components and enzyme activities of cytotoxicity among intensive agriculture farmers". Environ. Res., 102: 70-76.

Hissin, P. J. and Hilf, R. A. (1976) : “A fluorometric method for determination of oxidized and reduced glutathione in tissues". Anal. Biochem., 74: 214-217.

Jokanovic, M. (2001) : "Biotransformation of organophosphorous compounds". Toxicology, 166: 139-160.

Kakkar, P.; Das, B. and Viswanathan, P. N. (1984) : "A modified spectrophotometric assay of superoxide dismutase". Ind. J. Biochem. Biophys., 21: 130-132.

Kalender, S.; Ogutcu, A.; Uzunhisarcikli, M.; et al. (2005) : "Diazinon-induced hepatotoxicity and protective effect of vitamin $\mathrm{E}$ on some biochemical indices and ultrastructural changes". Toxicol., (211): 197-206.

Kalender, S.; Kalender, Y.; Durak, D.; et al. (2007): "Methyl parathion induced nephrotoxicity in male rats and protective role of vitamins $C$ and E". Pestic. Biochem. Phys., 88: 213-218.

Kaur, S. and Dhanju, C. K. (2004) : "Enzymatic changes induced by some organophosphorus pesticides in female rats". Indian J. Exp. Biol., 42: 1017-1019.
Khan, S. A.; Kahlid, L.; Rauf, M. A.; et al. (1986) : "Biological evaluation of Silybum marianum seed oil for nutritional purposes". Pakistan. J. Sci. Ind. Res., 29: 430-434.

Khan, S. A.; Ahmad, B. and Alam, T. (2006) : "Synthesis and antihepatotoxic activity of some new chalcones containing 1 , 4 - dioxane ring system". Pak. J. Pharm. Sci., 19: 290-294.

Koen, V. and Walterovab, D. (2005) : "Silybin and silymarin - new effects and applications". Biomed. Papers, 149: 29-41.

Lawrence, M. and Robert, H. C. (1993) : Methods of determination of blood urea and serum creatinine. In: Tietz Textbook of Clinical Chemistry. $2^{\text {nd }}$ ed., WB Saunders Co., London, P. 621.

López, O.; Hernández, A. F.; Rodrigo, $\mathrm{L}$; et al. (2007) : "Changes in antioxidant enzymes in humans with long-term exposure to pesticides". Toxicol. Lett., 171:146153.

Martignoni, E.; Blandini, F.; Godi, L; et al. (1999) : "Peripheral markers of oxidative stress in Parkinson's disease. The role of L-DOPA". Free Radic. Biol. Med., 27: 428-437.

Mira, L; Silva, M. and Manso, C. F. (1994) : "Scavenging of reactive oxygen 
species by silibinin dihemisuccinate". Biochem. Pharmacol., 48: 753-759.

Miyamoto, J. (1964) : "Studies on the mode of ac-tion of organophosphorus compounds. Part III. Activation and degradation of sumithion and methylparathion in mammals in vivo". Agric. Biol. Chem., 28: 411-421.

Monteiro, D. A.; Almeida, J. A.; Rantin, F. T.; et al. (2006) : "Oxidative stress biomarkers in the freshwater characid fish, Brycon cephalus, exposed to organophosphorus insecticide Folisuper 600 (methyl parathion)". Comp. Biochem. Physiol., $143: 141-149$.

Muriel, P. and Mourelle, M. (1990) : "The role of membrane composition in ATPase activities of cirrhotic rat liver: effect of silymarin". J. Appl. Toxicol., 10 : 281-284.

NCI (1979) : Bioassay of methyl parathion for possible carcinogenicity. Bethesda, MD: U.S. Department of Health, Education, and Welfare, National Institute of Health, National Cancer Institute, Carcinogenesis Testing Program. DHEW (NIH) Publication No. 79-1713; NCI-CG-TR-157, 112. Adapted From : ATSDR (2001) : Toxicological Profile For Methyl Parathion. Wilson, J. D.; Colman, J.; Wohlers, D.; Sutton, C. (Contributors), Department of Health and Human Services, Agency for
Toxic Substances and Disease Registry, Division of Toxicology and Environmental Medicine, Atlanta, GA (September 2001).

Nencini, C.; Giorgi, G. and Micheli, L. (2007) : "Protective effect of silymarin on oxidative stress in rat brain". Phytomedicine, 14: 129-135.

Pawlowska, D.; Moniuszko-Jakoniuk, J. and Lukaszewicz-Hussain, A. (19901991) : "Effect of pesticides on selected biochemical parameters in the serum and liver of rats". Rocz. Akad. Med. Bialymst., 35-36: 143-161.

Popovici, I.; Ungureanu, D. and Lupuoru, C. E. (2002) : "Reactivators of cholinesterase activity in methylparathion exposed rats". J. Prev. Med., 10: 79-84.

Pradhan, S. C. and Girish, C. (2006) : "Hepatoprotective herbal drug, silymarin from experimental pharmacology to clinical medicine". Indian J. Med. Res., 124: 491-504.

Ranjbar, A.; Pasalar, P. and Abdollahi, M. (2002) : "Induction of oxidative stress and acetylcholinesterase inhibition in organophosphorous pesticide manufacturing workers". Hum. Exp. Toxicol., 21: 179182.

Rashatwar, S. S. and Ilyas, I. C. (1984): "Effect of phosphomidon in a fresh water 
teleost fish-Nemachelius denisonii Day Histopathological and biochemical studies". J. Environ. Biol., 5: 1-8.

Rodrigo, L.; Hernandez, A. F.; LopezCaballero, J. J.; et al. (2001) : “Immunohistochemical evidence for the expression and induction of paraoxonase in rat liver, kidney, lung and brain tissue implications for its physiological role". Chem. Biol. Interact., 137: 123-137.

Rubin, C.; Esteban, E.; Hill, J. R.; et al. (2002) : "Introduction - the methylparathion story : a chronicle of misuse and preventable human exposure". Environ. Health Perspect, 110: 1037-1040.

Siess, H. (1991) : "Oxidative stress: from basic research to clinical application". Am. J. Med., 91 (Suppl. 3C): 38-85.

Solecki, R.; Faqi, A. S.; Pfeil, R.; et al. (1996) : "Effects of methyl parathion on reproduction in the Japanese quail". Bull. Environ. Contam. Toxicol., 57: 902908.

Suke, S. G.; Ahmed, R. S.; Pathak, R.; et al. (2008) : “Dose dependent effect of organophasphate compound on oxidative stress and induction of DNA damage". Biophys. J., 94 (Suppl. 1) : 946-951.

Szpunar, K.; Gorecki, P.; Wroncinski, T.; et al. (1976) : "Effect of silymarin on hepatotoxic action of lindane". Herba Pol., 22 (2): 167-171.

Tasduq, S. A.; Peerzada, K.; Koul, S.; et al. (2005) : "Biochemical manifestations of anti-tuberculosis drugs induced hepatotoxicity and the effect of silymarin". Hepatol. Res, 31: 132-135.

Tilgner, S. (1999) : Milk Thistle. In : Herbal Medicine : From the Heart of the Earth. $1^{\text {st }}$ ed., Pleasant Hill, Oregon, Wise Acres Publishing, P. 87.

Torres, R. L.; Torres, I. L.; Gamaro, G. D.; et al. (2004) : "Lipid peroxidation and total radical-trapping potential of the lungs of rats submitted to chronic and sub-chronic stress". Braz. J. Med. Biol. Res., 37: 185-192.

Varzi, H. N.; Esmailzadeh, S.; Morovvati, H.; et al. (2007) : "Effect of silymarin and vitamin $\mathrm{E}$ on gentamicin-induced nephrotoxicity in dogs". J. Vet. Pharmacol. Ther., 30: 477-481.

Valenzuela, A.; Aspillaga, M.; Vial, S.; et al. (1989) : "Selectivity of silymarin on the increase of the glutathione content in different tissues of the rat". Planta Med., 55 : 420-422.

Videira, R. A.; Antunes-Madeira, M. C.; Lopes, V. I.; et al. (2001) : “Changes induced by malathion, methylparathion and 
parathion on membrane lipid physicochemical properties correlate with their toxicity". Biochem. Biophys. Acta, 1511 : 360-368.

Walter, J. and Crinnion, N. D. (2000) : “Environmental medicine, Part 4 : Pesticides-biologically persistent and ubiquitous toxins". Altern. Med. Rev., 5 : 432447.

Wellington, K. and Jarvis, B. (2001) : "Silymarin: a review of its clinical properties in the management of hepatic disorders". BioDrugs, 15: 465-489.

Xing, L. X. and He, Y. W. (2007) : “Effects and mechanism of Silymarin on nonalcoholic steatohepatitis in rat". Chinese Journal of Gastroenterology and Hepatology, 16: 60-62.

Yamano, T. and Morita, S. (1992) :
"Hepatotoxicity of trichlorfon and dichlorvos in isolated rat hepatocytes". Toxicology, 76: 69-77.

Yavuz, T.; Delibas, N.; Yldrm, B.; et al. (2005) : "Vascular wall damage in rats induced by or-ganophosphorus insecticide methidathion". Toxicol. Lett., 155: 59-64.

Yavuz, Y.; Yurumez, Y.; Kücüker, H.; et al. (2007) : "Two cases of acute endosulfan toxicity". Clin. Toxicol., 45: 530-532.

Yoshida, S.; Inoh, S.; Asano, T.; et al. (1980) : "Effect of transient ischemia on free fatty acids and phospholipids in the gerbil brain". J. Neurosurg., 53: 323-331.

Yurumez, Y.; Cemek, M.; Yavuz, Y.; et al. (2007) : "Beneficial effect of $\mathrm{N}$ acetylcysteine against organophosphate toxicity in mice". Biol. Pharm. Bull., 30: 490-494. 


\section{القدرة التسينية الهحتملة لعقار السيليهارين ضد الإحهاد التأكسدى

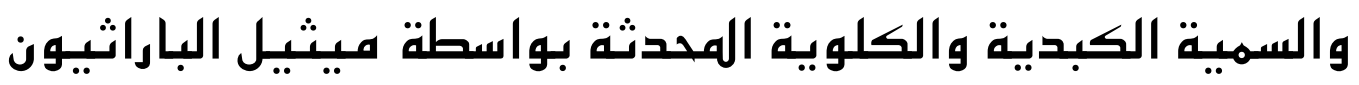

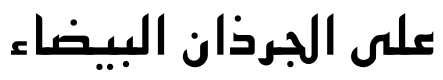

$$
\text { المشتركون فى البحث }
$$

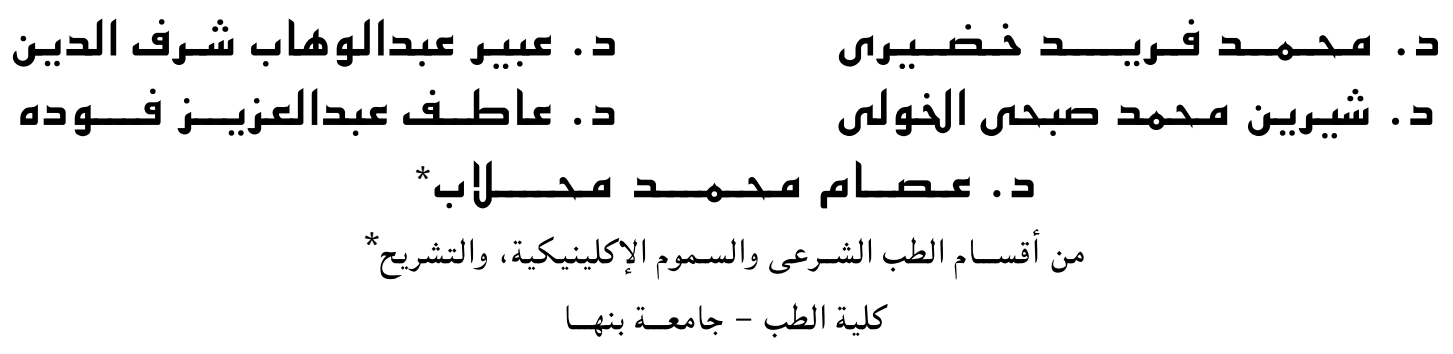

يعتبر ميثيل الباراثيون أحد المركبات الفسفورية العضوية السامة التى تستخدم لمكافحة الآفات فى المجال الزراعى منذ سنوات، هذا وقد وجد إن هناك مجموعات من الناس تكون أكثر عرضة لسمية هذا المبيد ألا وهم عمال المزارع ومن يقومون بعملية رش المبيد الحشرى وأيضاً عمال

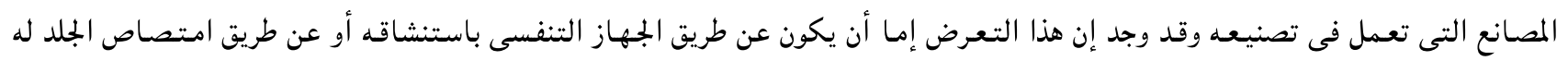
وأيضاً قد يكون عن طريق الفم.

وتهدف الدراسة الحالية إلى دراسة التأثير السمى لهذا المبيد الحشرى على دلالات مضادات الأكسدة وكبد وكلى الفئران وأيضاً إلى تقييم

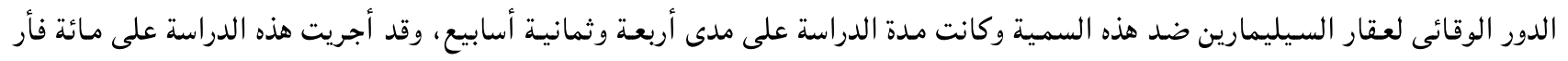

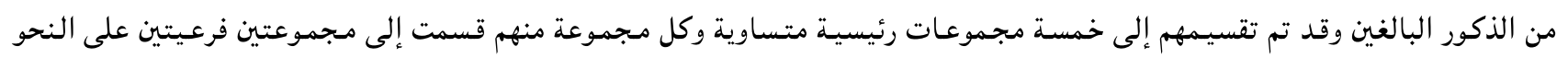

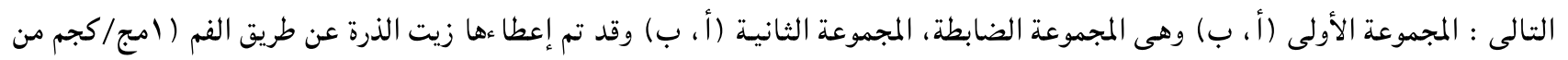

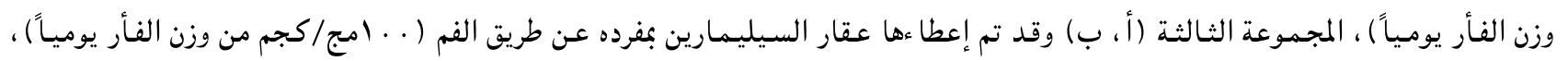

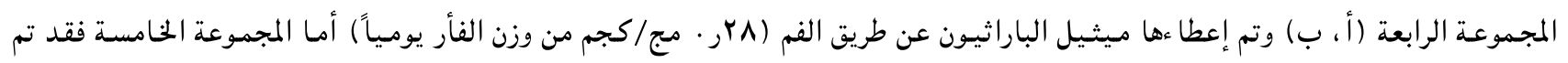

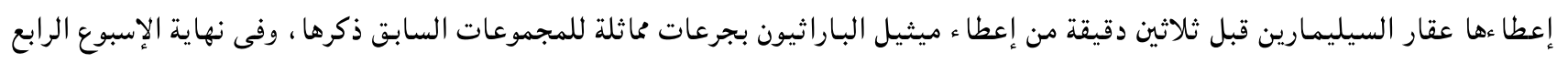

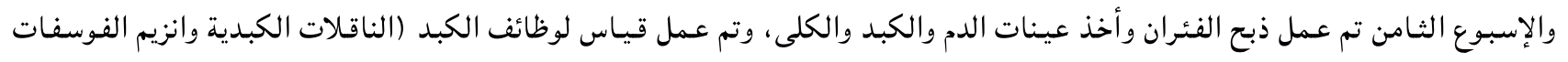

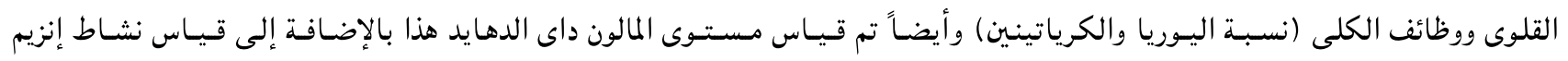

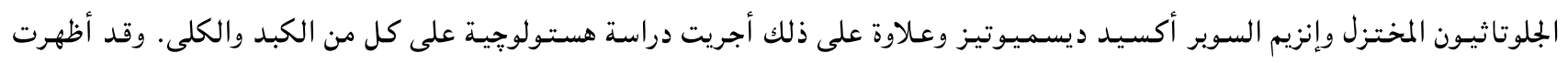

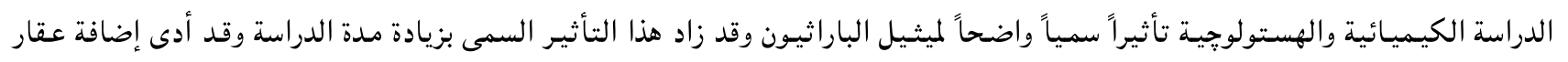

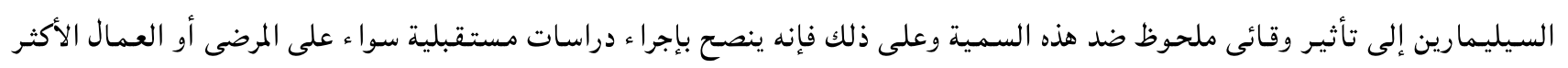

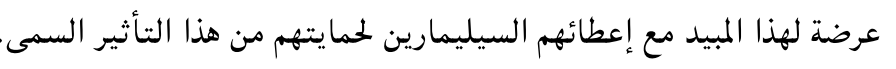

